\title{
SOME CLASSICAL HYPOTEXTS IN MARGARET DOODY'S ARISTOTLE AND POETIC JUSTICE ${ }^{1}$
}

\author{
F Pauw (Stellenbosch University)
}

The philosopher Aristotle appears in seven detective novels by the academic Margaret Doody in which he makes use of his investigative powers to solve murder mysteries. In Aristotle and poetic justice Stephanos, a friend of Aristotle, narrates how Anthia, the heiress of a silver merchant, has been abducted. While Stephanos and Aristotle pursue the abductor and the heiress on the road to Delphi, two murders complicate their challenge.

Doody's novel provides a convenient framework for opening a window onto the Greek world of $330 \mathrm{BC}$. In the body of the article, hypertextual allusions introduced by Doody are examined and evaluated, using a modified version of Genette's scheme as hermeneutic paradigm.

\section{Introduction}

The aim of this article is to examine hypertextual allusions in Margaret Doody's novel Aristotle and poetic justice. ${ }^{2}$ The novel is thus approached as a work of fiction which reflects literary and historical hypotexts rather than as a detective mystery. First, the author and her genre are introduced; then, narrative strategies are examined, the personae of the novel introduced, and a plot summary provided. After a theoretical section on hypertext, its application is tested especially on two levels: explicit quotations of or references to Greek literary sources, and implicit allusions to Greek hypotexts. In the penultimate section, I evaluate the way Doody employs her classical hypotexts, using my modified version of Genette's scheme as hermeneutic paradigm. In conclusion, I argue that the intertextual adaptation of the classics in modern novels is a valid mechanism for popularisation.

\footnotetext{
1 I wish to thank the anonymous referees of Akroterion for their useful criticism.

2 The function of allusions to Aristotle's Poetics in Doody's novel is discussed in Pauw 2010:26-60. Short sections which have been deemed informatively indispensable by way of background (Sections 1, 2, 3 and 4) will, perforce, partly overlap with the latter article.
} 


\section{The author and her genre}

The author of Aristotle and poetic justice, Margaret Doody (born 1939), is a professional academic who has lectured at a number of prestigious American universities. Although her field of specialisation is Restoration and Eighteenthcentury British Literature and the Novel, on which she has published extensively, ${ }^{3}$ she has also managed to write seven novels featuring Aristotle as detective. Her work has been translated into French, Italian, Spanish, Portuguese, Greek and Turkish. $^{4}$

Established authors such as Rosemary Sutcliff, Mary Renault and Colleen McCullough have pioneered historical novels about ancient Greece and Rome. In recent years, 'ancient detective fiction' has evolved as a separate sub-genre in which Lindsey Davis' M. Didius Falco (Mench 1993:54) and Steven Saylor's Gordianus the Finder (Mench 1993:49) are perhaps the best known Roman PI's. Compared to the now established canon of Roman detective fiction, however, ancient Greek detective fiction is such a novelty ${ }^{5}$ that Doody's Aristotle has yet to be properly evaluated.

\section{Narrative strategies and personae}

In Doody's novel Aristotle, as Makedonian ${ }^{6}$ metoikos, is in charge of the Lyceum in Athens. As a former student and now a friend of Aristotle, the Athenian Stephanos is used throughout as first-person narrator. One of the functions of Stephanos is to act as sounding-board for the amateur detective Aristotle to test the hypotheses of his mentor as he makes progress with his investigation. In this, Stephanos perhaps plays a role comparable to that of Sokrates' interlocutors in a Platonic dialogue, albeit with somewhat more independence of thought. In fact, the youthful and somewhat naïve Stephanos plays Watson to Aristotle's Holmes, thus acting as intermediary for Aristotle's thought processes and obviating the need for too many ex cathedra pronouncements by the Stageiran. As the most empirically minded and incorrigibly inquisitive of all Greek philosophers, Aristotle is ideally cast in his role as amateur detective. Aristotle had extensive knowledge of a wide range of subjects, but it is especially his knowledge of human psychology and logic that

\footnotetext{
3 http://www.nd.ed/ mdoody/. Retrieved 2010/08/04.

4 http://www.shotsmag.co.uk/shots23/intvus_23/mdoody.html. Retrieved 2010/08/03.

5 Apart from Doody's novels, the only example in this subgenre to which I have had access is José Carlos Samoza's postmodern whodunnit The Athenian murders.

6 I follow Doody in transcribing Greek names and terms, as far as possible, with Greek rather than Latinised orthography.
} 
stands him in good stead in the novel. He combines knowledge of human motives and a flair for making deductions to arrive at sometimes unexpected conclusions. As is implicit in the title, his poetics also comes into play.

The length of the novel (399 pages) can partly be ascribed to Doody's predilection for complicating the plot, but also to digressions on a Herodotean scale. The plot does not move inexorably forward with Aristotelian 'probability' or 'necessity', but is sometimes interrupted by episodic scenes. Delaying the plot by red herrings which ultimately prove necessary for the unfolding of the plot would have been a valid strategy to create suspense; however, these digressions are frequently incidental to the plot and apparently inserted primarily for the sake of intertextual games (see Section 6.3.5-9).

Since the cast of characters is rather large and mostly not known from classical history or mythology, the most important characters, and the relationship between them, will first be identified as an aide-mémoire before a summary of the plot is provided. Apart from Aristotle and Stephanos, the most important members of the large cast of characters are centred around an Athenian family of 'Silver Men'. The Athenians Lysippos and Timotheos are brothers - the former a rich silver merchant, the latter an unworldly Platonist. A third brother, Pherekrates, has recently died. His daughter Anthia (almost sixteen) has now become an heiress and is temporarily under the care of Lysippos. The beautiful Kallirrhoe of Ephesos is Anthia's slave. Lysippos has three children: Straton, Gorgias and Myrrhine. Gorgias, the eldest, has been missing in action after the Battle of Issos. The handsome Straton has a passion for flute-girls and horses. Their sister Myrrhine is rumoured to be mentally unbalanced. Other characters include Glaukon, a silversmith and a shrewd dealer, and Ammonios, a brothel-owner with a newlydeveloped interest in silver.

\section{The plot}

When Aristotle is requested by Lysippos to investigate the presumed abduction of Anthia and Kallirrhoe (53-55), ${ }^{7}$ he and Stephanos depart on horseback for Delphi (72). Beneath a sacred oak in the hills of Boiotia, they discover the body of Straton; Aristotle deduces that he was stabbed on three separate occasions by three separate assailants (106). They proceed, only to discover a second body at the crossroads made famous by Oidipous. It belongs to Ammonios, who has been run through with a boar-spear (137-138). After being joined en route by Korydon, Kallirhoe's lover, they recover Kallirhoe (238-241), and later Gorgias and Anthia

All quotations from and page references to Aristotle and poetic justice are based on the 2002 Random House edition. 
(287-304), unharmed in the vicinity of Delphi. Before falling to his death above Delphi (331), Timotheos admits to the murder of Straton and Ammonios (329).

Near the end of the novel, Aristotle, ready for his dénouement, assembles all concerned and goes through the case point by point:

The abductor was Glaukon (347-348); his prize was marriage to Anthia and thus a claim to her inheritance (353). In this, he was supported by Lysippos and especially by Straton $(352,357)$. Since Ammonios wanted to gain a silver contract (360), he was poisoned by Straton (362). An indisposed Ammonios therefore set off to Delphi (361); at the oak tree, he stabbed Straton, already wounded by Gorgias, and left him dying (363). Ammonios, however, had to bustle off when he was interrupted by Timotheos, who finished off Straton (365), his object being to get total control of the family wealth (368). From what Timotheos learned from Straton before his death, he realised that Ammonios knew too much (366). He therefore killed him with a boar-spear at the crossroads (367). Timotheos wanted to kill Lysippos as well (369); moreover, he could lay his hands on the family money by marrying Myrrhine (371).

\section{Hypertext: Theory}

In this section, I examine the ways in which Doody makes use of different hypotexts in the course of her novel. With that in mind, the meaning I attach to terms such as intertext, hypotext and the like should first be clarified.

In the introductory chapter to his seminal work on hypertextuality, Gérard Genette distinguishes five types of transtextual relationships, of which four can be applied to Doody's novel: ${ }^{8}$

(i) intertextuality, where text $\mathrm{A}$ is present in text $\mathrm{B}$ in the form of quotations or allusions (Genette 1993:1-3);

8 Here, hypertextuality, consisting of five subcategories, is used as 'umbrella term' or catch-all for an all-encompassing textuality.

9 According to J P Sullivan 1994:9, 'Intertextuality [...] offered itself as a more dynamic form of Quellenforschung, the traditional search by philological commentators for models, parallels, allusions, echoes, borrowings, and even plagiarism in ancient authors. At the same time it connects with such ancient concepts as imitatio and aemulatio'. Don Fowler 2000:121, again, argues that '[t]raditionally, there has been much uncertainty about what the function of allusion was: was it to demonstrate learning, to pay homage to a predecessor, to acknowledge a debt, to borrow lustre from a classical model? [...] In contrast, the focus in recent years has been on the way in which intertextuality creates meaning in texts through a dialectic between resemblance and difference. Although the difference remains highly significant, there has been a major change in the way that the earlier texts are again now seen to leave 'traces' of themselves in the target text'. 
(ii) paratextuality, according to which literary conventions such as title and subtitles, notes, prefaces, marginal notes, illustrations and mottos are regarded as paratexts (Genette 1993:3-4);

(iii) architextuality, in terms of which generic types are identified and grouped together (Genette 1993:4); and

(iv) hypertextuality, ${ }^{10}$ where text $\mathrm{B}$ (the hypertext) is derived from text $\mathrm{A}$ (the hypotext) without B being a philological or literary commentary on A (Genette 1993:5-7).

Genette (1993:398-399) compares the process by which text A is transformed into text $\mathrm{B}$ to the creation of a palimpsest. A real-life palimpsest is the result of one or more texts written over the original on a vellum or papyrus manuscript. When applied to comparative literature, the metaphor of a palimpsest is used in similar fashion to describe the result of Text B being 'superscripted' or 'superimposed' on Text A. ${ }^{11}$ An obvious example of such a 'hypotext' cited by Genette (1993:5-6, 307-309) is the Odyssey, with Vergil's Aeneid and James Joyce's Ulysses as two of its many 'hypertexts'.

Some recent novels, however, provide material for hypertextual study across generic parameters. ${ }^{12}$ From a generic point of view, two ways of adapting a classical hypotext thus present themselves:

(i) using a Greek or Roman original in a given genre as a source for a modern hypertextual adaptation within that genre; and

(ii) adapting a classical original in a certain genre to a hypertext in a different genre.

To these, two more could be added:

(iii) using an historical or biographical novel to portray a particular period or historical personage by infusing 'objective' history with 'subjective' fictionalisation; and

10 Here, the term hypertextuality is more specific: it is one of the five subcategories of transtextual relationships.

11 Michael Alexander (quoted by Hutcheon 2006:6) punningly speaks of the 'palimpsestuous' relation between works: 'If we know that prior text, we always feel its presence overshadowing the one we are experiencing directly'. (Genette 1993:399, however, ascribes the term 'palimpsestuous' to Philippe Lejeune).

12 I have argued that this applies to Donna Tartt's The secret history (Pauw 1994, 1995) and to William Golding's The double tongue (Pauw 2008), where Greek tragedies (Euripides' Bacchae and Ion respectively) are used as acknowledged hypotexts. 
(iv) writing a novel or poem which contains brief and scattered allusions to various classical sources without owing allegiance to any master hypotext..$^{13}$

\section{Hypertext: Application}

\subsection{Historical intertext}

The basis for intertext can be historical rather than literary. ${ }^{14}$ In a previous article, I demonstrated how Doody's novel qualifies as faction, since all her characters even Aristotle, who has an historical equivalent - are fictional, but the setting can be correlated with what is factually known of Athens and Delphi in 330 BC. ${ }^{15}$ Doody's historical intertext is manifestly of great importance in the novel. Frequently, reference is made by the characters to historical events in the Greek world. This is no mere empty parading of historical knowledge on the part of the author, who claims that she regularly checks her 'facts' with classicist friends, ${ }^{16}$ but provides an historical intertext commensurate with the late classical era. Not surprisingly, in the fictional world of $330 \mathrm{BC}$ such references usually have a bearing either on the conquests of Alexander the Great or on the biographical background of Aristotle.

Moreover, to lend authenticity to the historical basis of Doody's novel, it is fairly liberally sprinkled with Greek technical terms which refer, for instance, to offices and customs. ${ }^{17}$ These terms have not been used merely to impress the reader

13 For the sake of brevity, (i) will be called intrageneric; (Homer $\rightarrow$ Vergil); (ii) transgeneric (Euripides $\rightarrow$ Tartt); (iii) faction (i.e. a conflation of historical fact and fictional elements) and (iv) mosaical or kaleidoscopic, since such allusions appear as random snippets comparable to a fragmented mosaic or the shimmering chromatics of a kaleidoscope. These four theoretical options frequently overlap. Thus, any of the last three could be applied to Doody's novel. To complicate matters, there is sometimes overlapping between the terms intertext and hypotext, depending on the extent of intertextual 'borrowing': when does a text represent a mere intertextual echo, and when does it merit the status of a solid hypotext? It appears as if most authors use the term intertext as a convenient compromise.

14 The following remark by Charles Martindale 1991:52 illuminates this use of the term intertext: '[...] by text is meant any vehicle of signification, so that in this extended sense a mosaic or a marriage ceremony is a "text" as much as a "book".

15 See Pauw 2010:31-35 (4. Faction).

16 http://www.shotsmag.co.uk/shots23/intvus_23/mdoody.html. Retrieved 2010/08/03.

17 These include the following:

Offices and titles such as archon / eponymous official (2), prytaneis / 50 office-bearers per month (3), Poletai / Board of Public Contracts (3), sitophylakes / 'Grain Guardians' (8), ephebe / military conscript at the age of 18 (9), metoikos /resident foreigner (29), 
but are functionally integrated, as can be deduced from the fact that, by and large, they are concentrated in the first two chapters, where they have the function of stressing the 'Greekness' of the atmosphere from the outset. Moreover, most of these terms are specifically Athenian, and after the opening setting in Athens the scene is moved to Boiotia, Delphi and elsewhere, so that they diminish in frequency.

\subsection{Literature: Explicit hypotexts}

Such is the importance of literature in Greek culture that no novel with a classical Greek setting, especially one in which Aristotle features, would carry conviction if it fails to contain ample references to Greek literature. In this, Doody does not disappoint the reader, for there is sufficient allusion to archaic and classical literature to ring true. In this section, I examine Greek literary hypotexts or intertexts which are explicitly identified per author or title, leaving unidentified but implicit allusions for the next section. Authors who are mentioned in this section, or from whose works there are quotations, are Homer, Aiskhylos, Sophokles, Herodotos, Aristophanes, Plato and Theophrastos.

\subsubsection{Homer}

Allusions to Homer appear on a number of occasions in the course of the novel. The first instance is where, after introducing himself to Aristotle and Stephanos, the free-born slave Korydon attempts to establish his pedigree by claiming: 'I can recite the Iliad, and read it also. I can tell you every detail of Akhilleus' shield, and describe Odysseus' travels' (161). The reference to Akhilleus' shield is based on the hypotext of Iliad 18.558-709; the phrase 'Odysseus' travels', of course, refers to most of the Odyssey. Korydon's claim demonstrates in what high regard knowledge of Homer was held, four hundred years after the Iliad, as a mark of education and culture. After all, at the time of Korydon's claim Alexander was reputed to have taken the Iliad along on his conquests as a military guidebook. ${ }^{18}$

basileus / chief archon (34), oligarkh (189) and proxenos / representative abroad (190); buildings and localities such as Tholos / building where prytaneis assemble (3), Emporion / harbour market area (8), adyton / sanctuary (217) and Omphalos / navel stone (318); months such as Anthesterion / spring month (1) and Gamelion / Wedding Month (26); clothing such as himation / cloak (186) and khiton / mantle (327); and other terms such as Anthesteria / Flower Festival (2), ateleia / exemption from tax (15), khoes / wine jug (28), symposium / drinking party (38), hubris (246), bouleusis / counsel (307) and peripeteia / reversal (392). (Only the first occurrence per item is acknowledged). 
Later, during their tour of Delphi, Aristotle and Stephanos visit the Leskhe of the Knidians, viewing a large picture with scenes of the Underworld by Polygnotos. Aristotle finds the scene where Odysseus attempts to embrace the shade of his mother Antikleia especially disturbing; he quotes the passage in the Odyssey where this is described:

Thrice I tried as my heart led me to clasp her in my arms,

Thrice she drifted away from my arms like a shadow or a dream (210).

The Greek intertext (Od. 11.206-207) reads as follows: $\tau \rho i \varsigma ~ \mu \grave{\varepsilon} v$

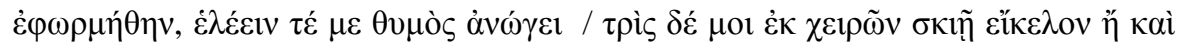

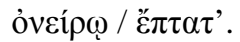

To account for his empathetic response to Odysseus' grief, Aristotle explains that his own mother died when he was eight and his father when he was ten.

\subsubsection{Aiskhylos}

The murders in Doody's novel, and the events preceding them, are occasioned by greed. So as to highlight the lure of money in Ammonios' plans, Aristotle explains (360): 'I'm afraid what Aiskhylos in The Persians calls our Athenian "treasure in the earth" has very mixed effects on the human mind'. The intertext in The

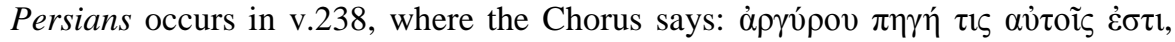

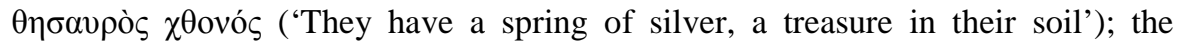
allusion is to the discovery and mining of silver at Laureion in Attika in c. $484 \mathrm{BC}$, to which Polemon also refers elsewhere: 'The wealth of mines had made Athens great in the past. Wasn't it Themistokles or somebody who had two hundred warships built from the proceeds?' (10). Polemon's remark finds literary corroboration in Plutarch, ${ }^{19}$ where it is stated that the money was used to build triremes for the war against Aegina.

\subsubsection{Sophokles}

When Aristotle and Stephanos are still on the trail of Anthia, Stephanos has occasion to speculate on the identity of the abductor and the murderer(s), and argues that 'it would make better sense if Polemon were the Abductor and killed Straton. Then Anthia piously insisted on burying Straton properly, like an Antigone' (228). The allusion is to Sophokles' Antigone, where the eponymous

19 Plut. Vit. Them. 4. 
character insists, against the decree of King Kreon, on giving her rebel brother Polyneikes a proper burial by ceremoniously sprinkling his corpse with dust on two occasions and honouring it with the customary three ritual libations (vv. 245-247, 423-431, 1196-1204).

\subsubsection{Herodotos}

When Korydon, in the course of his long-winded narration, mentions the names of the Persian leaders Orontobates and Memnon, Stephanos remarks: 'Wonderful names! Like reading Herodotos' (167).

As ethnographer, Herodotos was interested in the cultural differences between peoples and countries. Although his Histories also deals, for example, with Egyptians, Scythians, Thracians and Taurians, the culmination of his account is the growth of the Persian empire since $560 \mathrm{BC}$ and the clash between Greeks and Persians in the Persian Wars of 490-479 BC. The association between Herodotos and Persian names is thus warranted, although Orontobates and Memnon are not names that feature in Herodotos.

In Korydon's narration, of course, Orontobates and Memnon are not contemporaries of the Persian Wars but of Alexander. According to Badian (1999:1204-5), there were two strategoi in this period named Memnon: a Thracian and a Rhodian, both involved in opposing Alexander's conquest of Persia. It is clear that the latter is meant. Orontobates (or Orontopates) was a younger brother of the Karian satrap Maussolos; he defended Halikarnassos against Alexander's assault (Wiesehöfer 2000:50-51).

\subsubsection{Aristophanes}

On the first day of the Anthesteria, Stephanos recounts, 'I took jugs of the new wine to the shrine of Dionysos in the Marshes - that shrine where one can sometimes hear the frogs croaking, as Aristophanes points out in his Dionysosplay' (27). The reference is to the false parodos of Frogs, where the secondary

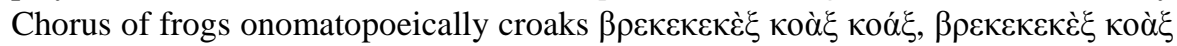
$\kappa o \alpha ́ \xi .{ }^{20}$ The connection between Dionysos and wine reminds one of the scene in Akharnians where Dikaiopolis, with comical para prosdokian, celebrates the Country Dionysia 'in the wrong place at the wrong time' (Sommerstein 1973:44), i.e. in the city instead of in the country demes and in February (the time for the Anthesteria) instead of December.

20 Ar. Ran. 209-210. 
When Aristotle and Stephanos, the former encumbered with his firepot, take to the hills so as to outmanoeuvre possible pursuers, Aristotle describes them as 'Ridiculous. Like the old men in Lysistrata, climbing up the Akropolis laden with firepots' (144).

The primary plot of the Lysistrata is a pan-Hellenic sex-strike by younger women so as to force the men to end the war. This reference is to the secondary plot, the occupation of the Akropolis by the old Athenian women and the old Athenian men's efforts to liberate it. In the course of this comic gender battle the half-chorus of old women attempts to douse the fire carried up in pots by the halfchorus of old men attempting to drive the women off the Akropolis. Thus, they complement the younger women's sex strike in a more slapstick way.

With reference to the dedications made and shrines erected in Delphi by Greek states to commemorate victories over other Greek states, Aristotle remarks: 'Aristophanes in Lysistrata suggests that all Greeks should live in harmony and union, as men who worship the same gods' (205). The pan-Hellenic peace advocated in this Aristophanic hypotext, and later advocated by Isocrates, would remain a pipe-dream, however, as witness the examples of Aigospotamoi, Leuktra and the Sacred Wars preceding this passage: in the eighty years between the performance of Lysistrata and this fictional conversation, first Spartan, then Theban and then Makedonian striving for hegemony would undermine any attempt at Hellenic unity.

Toward the end of the novel, Aristotle attempts to apply the generic parameters of tragedy and even of comedy to their experiences of the previous days. To demonstrate the difference between tragedy and comedy, he takes Aristophanes as example: 'In comedy, two or three families in a country village is the very thing to work on - as we see in a play like The Akharnians or some modern comedies' (392-3). In Aristophanes' Akharnians, the family of the protagonist, Dikaiopolis, appears on stage in the parodos. But although the peace he concludes with the Spartans is ostensibly for the benefit of his family, it soon proves to be solely to his advantage. His family does not appear on stage again and does not share in the celebrations with which the comedy concludes. In fact, in the komos scene his wife has been supplanted by a girl of uncertain morals. The only other group in Akharnians potentially qualifying as a family is the Megarian and his two little daughters, who play but a cameo role, providing the opportunity for comic banter and scurrilous puns. It therefore appears as if Aristotle has overstated his case. He would have been better served by an example from Middle and early New Comedy (as implied by 'some modern comedies'), where the focus is on the oikos. In Old Comedy, the focus was famously on the public sphere of the polis, with little scope for the private sphere of the family. 


\subsubsection{Plato}

There are numerous references to Plato in the novel, of which most pertain to the avowed Platonist Timotheos. Upon meeting Stephanos at the start of the novel, Lysippos admits that 'I cannot account myself a philosopher. Nor even a true guardian, the kind Plato talks about in his Republic' (19). The reference is to the militia ( $(v \dot{\lambda} \alpha \kappa \varepsilon \varsigma)$ in Plato's ideal state, to whose education most of The Republic is devoted; they are elevated in status above the workers, but beneath the status of the philosopher-king. Later, Kleiophoros claims that Timotheos would fare better at arguing if he would get married again, his argument being that 'Sokrates himself might not have been so famous for arguing had he not been married' (25). Much later, during their visit to Delphi, Timotheos asks, rhetorically: 'Did not Sokrates himself consult the Pythia?' (279). The hypotext for this allusion is the Apologia (20e-21a), where the Platonic Sokrates describes how not he himself, but his friend Chairephon asked the Delphic oracle who was the wisest man alive. The oracle answered that no man was wiser than Sokrates.

Timotheos, a staunch Platonist, regards himself as a lover of the Beautiful and the Good (65); in support, he quotes from the Symposium (65-66): 'The soul of the true lover, passing beyond particular things, climbs aloft to the highest beauty so that in the end he knows the being of Beauty itself, pure and unmixed, uncontaminated with the flesh and colouring of humanity and that sort of transient and dying stuff'. ${ }^{21}$ Timotheos is dismissive of his non-philosophical brother Lysippos: 'He has set his mind on particulars, material things, mere shadows and shows of the real. If he had learned, as Plato says, to love the Good, he would know that what happens - or seems to happen - in this shadowy cave ${ }^{22}$ is not of importance. He sets his heart on that which passes away, on mortal flesh subject to decay' (279). Timotheos' Platonic otherworldliness is dangerous: he thinks that his Platonism elevates him above ordinary mortals (328), and it is this hubris that leads to the callous murders he commits. In fact, in another passage (329) he claims: 'I am a midwife of the spirit, true descendant of Sokrates and Plato. Yet I was despised'. Clearly, he had a chip on his shoulder: he even wanted to found another Akademeia, with himself as head (372).

21 The intertext for this quotation is Pl. Symp. 211d-e.

22 The metaphor of the cave is described in Pl. Resp.514a-518b. For a comparable passage, see p.308, where Gorgias disparages Aristotle's suggestion to pray to Apollo: 'Phantom and illusion. The shadows of the imitation of things, flickering on cave walls'. 


\subsubsection{Theophrastos}

Theophrastos would become Aristotle's successor as head of the Lyceum from c. $322 \mathrm{BC}$ to $c .287 \mathrm{BC}$ (information to which Stephanos could not have been privy) and, in this capacity, would further the peripatetic modus operandi of collecting data from the natural world before speculating on universals. In discussing what he perceived as Theophrastos' dull and methodical temperament, Stephanos mentions that 'Theophrastos has written a book of Characters which are much admired [...]. These things Theophrastos [...] wrote down in the hope of classifying humanity as he did his horticultural specimens' (71). John Scarborough points out that Theophrastos' botanical works were definitive until the widespread acceptance of the Linnaean systems of nomenclature toward the end of the eighteenth century. ${ }^{23}$ Theophrastos may have been no Aristotle, but in this condescending judgment of the Characters Stephanos is perhaps being unfair. The classification system underlying the Characters is generically different from that relating to botanical specimens, being based, as it is, on a stereotyped conflation of caricature and reality. ${ }^{24}$

\subsection{Literature: Implicit hypotexts}

In the previous section, hypertexts were examined of which the corresponding hypotexts are more or less explicitly identified per author and/or work. In this section, I examine hypertexts which contain allusions to unacknowledged, and thus implicit, hypotexts. Some of these are inserted as vignettes, with minor characters making cameo appearances. Regarding implicit hypotexts, Umberto Eco (1979:21) believes that 'every character (or situation) of a novel is immediately endowed with properties that the text does not directly manifest and that the reader has been 'programmed' to borrow from the treasure of intertextuality'. In terms of readers' response, the distinction between explicit and implicit hypotexts is important, because identifying the latter poses a bigger challenge to the critic in that it presupposes a readier intuitive acquaintance with Greek literature.

bmcreview=brynmawr.edu@mscv6.net. Retrieved 2009/12/27.

24 bmcreview=brynmawr.edu@mscv6.net. Retrieved 2009/12/27. 


\subsubsection{Hesiod}

In the very first lines of Doody's novel, Stephanos invokes the Muses:

Inspire me, $\mathrm{O}$ waters of the Kastalian spring, that I may speak well-omened words. Hear me, O Muses who dwell by the Spring of Hippokrene, Thalia and Melpomene, and speak through me [...]. May I also honour the great Oracle at Delphi. Apollo be praised (1).

This invocation is reminiscent of Hesiod, in particular of the opening lines of the Theogony, where the Helikonian Muses (Movбó $\omega v$ 'E $\lambda \iota \kappa \omega v i \alpha ́ \delta \omega v, ~ v .1)$ are

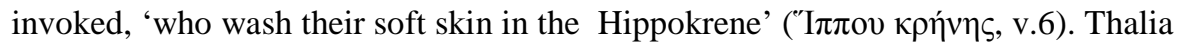
and Melpomene (v.77) are two of the nine Muses listed by Hesiod. Melpomene was regarded as Muse of tragic poetry in late Hellenism (Von Geisau 1979:1183), Thalia of comedy (Von Geisau 1979:643). In view of the nature of Aristotle's and Stephanos' discussions of tragedy and comedy late in the novel, Stephanos' invocation of these two Muses is justified. Although Doody retains the conventional homage to the Hippokrene Spring and thus to Helikon as seat of the Muses, the reader is soon prepared for a shift of location when the Kastalian Spring and the Oracle of Apollo at Delphi are invoked. Although Aristotle and poetic justice is Athenocentric, Delphi will play a pivotal role in the novel. The murders are committed on the way to Delphi, but cleared up by Aristotle in Delphi itself. Moreover, Gorgias, Anthia and Myrrhine are discovered in, and Kallirrhoe near, Delphi, and Timotheos commits suicide in Delphi. Thus, the opening invocation to the Kastalian Spring is warranted.

\subsubsection{Orestes and Elektra}

An important mythological hypotext in Doody's novel is provided by the fate of Orestes and Elektra after they have murdered Aigisthos and Klytaimnestra in retaliation for the latter's murder of Agamemnon. This is supported by at least two explicit references and various implicit allusions to the Orestes and Elektra tragedies of Aeschylos, Sophokles and Euripides.

The first such allusion occurs when Stephanos explains the background of the Anthesteria festival: 'Pursued by the Furies for his matricide, Orestes was tried in Athens and at last freed by the decree of Phoibos Apollo' (2). The literary hypotext for this is the last part of the Choephoroi and the Eumenides of Aeschylus. The origin of the Silent Dinner, as Stephanos informs the non-Athenian Aristotle, can also be traced back to Orestes, who was offered hospitality by the Athenians but could not eat or drink with them on account of his blood-guilt (37). This leads to Aristotle asking Stephanos whether he prefers Sophokles' depiction 
of Orestes to that of Aiskhylos (38). After the Silent Dinner, Stephanos hears a conversation between a man and a woman talking about attempted murder and revenge (45-47):

'The lock of hair on the shrine - I recognised the colour. Where is my brother? Where is his grave?'

'There is no grave. Only the dead have graves. Look — here is the ring my father gave me, with his seal; you may feel the pattern with your fingers. Do you believe me now?'

'O gods! My dear, dear brother! Have you come home at last? You don't know how they treat me!'

'Hush! Be careful. It wasn't a mistake, it was attempted murder'.

[...] 'We must have revenge.' [...]

'The word of Apollo is of great power and cannot fail. His voice, urgent, insistent, drives me to dare this danger' ${ }^{25}$

Stephanos, frightened, naïvely deduces that the two participants in the literary dialogue are Orestes and Elektra. The participants later (301) prove to have been Myrrhine and Gorgias. Just as Orestes and Elektra could plot revenge against Klytaimnestra, so Gorgias and Myrrhine, in imitation of classical hypotexts by the tragic poets, plan to take revenge on Straton.

This passage is a conflation of passages deriving from Aischylos' Choephoroi and Sophokles' Elektra. In fact, such a kaleidoscopic patchwork of originally discontinuous verses poses a challenge to the would-be sourcehunter. ${ }^{26}$

When Aristotle and Stephanos later discover Gorgias in the cave, the latter is experiencing hallucinations (291): 'O gods! I can see them again! They're coming - they will have me! With faces like dogs. With bloody eyes!' Such phantoms are reminiscent of the dog-like Furies pursuing Aeschylos' or Euripides' Orestes, or the hallucinations of Goethe's Orest. Indeed, Aristotle quotes the following lines, identified by Stephanos as coming from Euripides' Orestes, so as to highlight the remorse of Gorgias and Myrrhine:

25 Other references to this conversation occur on pp.266-267, 301, 347 and 384.

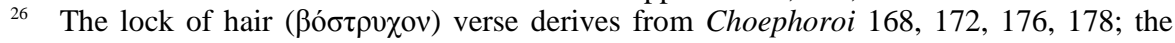

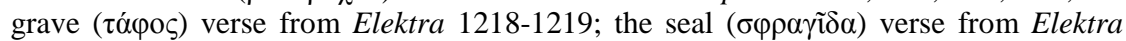
1222-3; the homecoming verse from Elektra 1232-1235; the Apollo verse (his word is of great power: $\mu \varepsilon \gamma \alpha \sigma \theta \varepsilon v \eta ́ s)$ from Choephoroi 269-270. 
Dark Eumenides, wide-winged above us

Soaring in free space of clear arching sky,

Avenging injustice, blood-guilt avenging,

Hear me and my cry

Imploring, imploring:

Forgive the sad son of great Agamemnon,

Forgetting the mania, the cruelty of madness - (309).

This passage comes from the first stasimon (vv.321-327) of the Orestes, where the Chorus of Argive women beseeches the Eumenides to release Orestes from his torments.

On a different occasion, Aristotle muses on the ancient perception of historicity in tragedy: 'Tragedy, it is true, usually deals with historical persons, and often with what has manifestly happened. Yet different poets give different accounts of the same persons. Aiskhylos and Euripides created different Elektras, for instance. Who is the real Elektra?' (219).

As regards Aristotle's claim concerning Elektra, we are, as it happens, in the exceptional position to evaluate it because Elektra tragedies by all three of the major fifth-century tragic poets are extant: Aeschylos' Choephoroi, Sophokles' Elektra and Euripides' Elektra. The psychology and motivation of Elektra, her relationship with Orestes, and her role in the matricide are indeed portrayed differently in these three versions. To compare but the first variable: the Aeschylean Elektra is motivated not so much by love of her father as by hatred of her mother and obedience to Apollo (De Marre 1988:7); the Sophoklean Elektra by love of her father and a sense of duty, obedience to the oracle playing a lesser role (De Marre 1988:11). In Euripides, the heroic is debunked and the full horror of the murders depicted, with Elektra showing hypocritical concern for her mother (De Marre 1988:23, 38). ${ }^{27}$

\subsubsection{Menander}

On their way to Delphi, Aristotle and Stephanos are looking for water near the Boiotian border when they encounter a boy from Athens who is visiting his uncle's farm (78). His name is Menandros and he directs them to the homestead of one Smikrenes, a curmudgeonly old man (79), where they might find water at one of

27 In view of the literary-theoretical importance attached to tragedy as a yardstick for evaluating the 'hero' and the other participants in the murder mystery, especially toward the end of the novel (Pauw 2010:48-51), the Orestes-Elektra theme should generically gain in significance. 
the two shrines. Smikrenes lives with his daughter and does all the work himself. $\mathrm{He}$ is so misanthropic that he is reputed to chase everybody off his land. When they meet Smikrenes, he does, in fact, throw clods of earth at them, forcing them to leave empty-handed (83). Smikrenes' daughter, Philomela, however, calls them aside with a promise of water, but when she and an old servant go off to fetch water, the servant lets the pitcher drop into the well (85). Smikrenes' attempt to fish it out with his hoe ends with him falling into the well, but when Stephanos uses a rope to save him (87-88), he earns Smikrenes' gratitude and Philomela's admiration. Before they leave, Smikrenes has changed from a cantankerous recluse to being hospitable and sociable.

This is the most effective of Doody's hypertextual games, because

(i) the fictional Menander's age is perfectly commensurate with the known biographical facts of the historically real Menander, who would have been eleven years old in spring 330 BC. Menander claims, in fact, that 'I will read all the great books and the poems and the plays. Then I will write some myself and be famous and get prizes like Euripides' (94).

(ii) Smikrenes' fate, as well as his metamorphosis, is comparable to that of the grumpy Knemon in Menander's Dyskolos, produced in 317/6:

A cantankerous old man turns visitors away, loses his pitcher in a well, falls into the well in an attempt to retrieve the pitcher, is rescued by the visitors and becomes more amicable. The reader should thus imagine the real Menander as using his memory of the fictional situation of thirteen years before in creating this play. When, at the end of the novel, Theophrastos describes Smikrenes as 'an irascible man' (398), it echoes not only the title of Menander's play, but also of more than one of the character types in Theophrastos' own Characters ${ }^{28}$ moreover, Theophrastos himself is drawn, ironically, as rather dour and surly (71).

(iii) Philomela provides a love interest for the wifeless Stephanos: with the blessing of the Delphic Oracle $(319,388)$, of Smikrenes (395), and of Aristotle (389), he decides to marry her. Thus, the novel ends on a romantic note, just like New Comedy.

(iv) New Comedy provides a further hypotextual basis for Doody's novel in that Smikrenes' name occurs in at least three New Comedy plays, ${ }^{29}$ as do the names Myrrhine and Gorgias. ${ }^{30}$

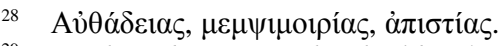

29 In The arbitration, The shield and The Sikyonian (Miller 1987:82, 126, 146). 


\subsubsection{Homer}

There are at least three implicit allusions to Homer in Doody's novel, but only one need concern us here. ${ }^{31}$ After discovering the body of the murdered Straton, Aristotle asks Stephanos: 'Do you remember [...] what Patroklos says when he is dying?'

Stephanos replies: 'Well, Patroklos is run through by a spear - Hektor's spear, but only after Patroklos was assaulted by Phoibos Apollo and also struck by Euphorbos. So Patroklos says to Hektor: "You are the third one to kill me"" (106).

This Homeric allusion is based on the intertext of the Iliad 16.849-850,

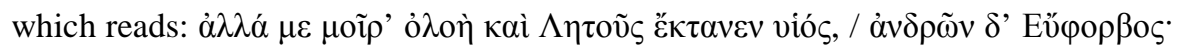

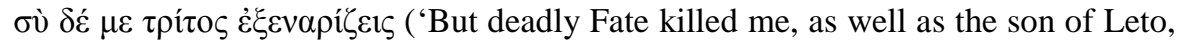
and of men, Euphorbos; and you are the third one to slay me'). Stephanos' quotation becomes significant when Aristotle later $(344,371)$ identifies the three different perpetrators who were consecutively and independently involved in the wounding and ultimately in the death of Straton: Gorgias, Ammonios and Timotheos.

It is difficult to avoid the conclusion that Doody devised her plot with this Homeric hypotext in the back of her mind. Had it not been for Moira, Apollo and Euphorbos, poor Straton would probably not have been so mangled: his intertextual debt to Patroklos comes at a price.

\subsubsection{Anaxagoras and Lykidas: A pastoral singing contest}

In the course of their travels through Boiotia, Aristotle and Stephanos run into Anaxagoras, a goatherd, and Lykidas, a shepherd, who ask Aristotle to adjudicate a singing contest between them (118). This bucolic interlude does not contribute to the plot, but is an unwarranted interruption. Why, then, has Doody seen fit to insert it?

Lykidas is a name traditionally used for shepherds; it crops up in four Greek pastoral poems (Holden 1974:242). Moreover, some of Theokritos' poems contain singing matches between shepherds. Since the fictional singing match antedates Theokritos' poems by at least half a century, perhaps Doody wanted to highlight the pre-literary origin that this genre must needs have had. As regards Anaxagoras, however, there is no example of this name in Holden's translation of Greek pastoral poems. While there is nothing to prevent a goatherd being called

30 In Dyskolos (Old Cantankerous), The farmer and The hero (Miller 1987:22, 186, 208).

31 The other two allusions to Homer (pp.49-50, 392) will not be discussed here, as they have already been dealt with in the article on the role of the Poetics in Doody's novel (Pauw 2010:36-37, 51-52). 
Anaxagoras, one would rather associate his name with Ionian philosophy. As will be seen again, Doody is fond of springing surprises, chronologically and generically.

\subsubsection{The Anacreontic Monkees}

The morning after Aristotle and Stephanos attended a marriage feast in Boiotia, a woman starts singing 'an ancient ballad' (132) with the opening words

Love came knocking at my door. / "Open then, and let me in!"

This is suspiciously reminiscent of the opening line of a song by the pop group the Monkees in 1967:

When love comes knockin' at your door / Just open up and let him in.

The rest of the ballad (34 lines) is based on the hypotext of a poem in the Anacreonta. ${ }^{32}$ The opening lines of Doody's song, however, are much closer to the line of the Monkees than to Anacreontea 33, of which the relevant lines read as follows:

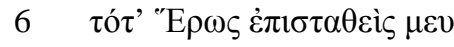

Love stood at my bolted door

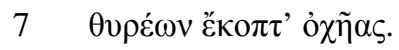
And began knocking.

$$
\text { [...] }
$$

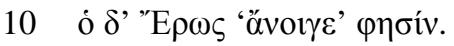

Love said, "Open up!"

More importantly, it would have been chronologically impossible for a character in $330 \mathrm{BC}$ to remember a line from the Anacreontea, for these poems were "not composed before the Hellenistic period, most of them perhaps not until the Roman and Byzantine eras' (Campbell 1988:10). In fact, Campbell (1988:16) dates the group to which Anacreontea 33 belongs 'to the last centuries $\mathrm{BC}$ and to $\mathrm{AD}$ 1-138'. It would appear, therefore, (i) that Doody has slipped up on the dating of the Anacreontea, but, quite apart from that, (ii) that she has inserted a blatant, and parodic, anachronism in the Monkees quotation.

I cannot but think that this anachronism is Doody's way of having a bit of fun at the expense of the unwary or the gullible. If one discounts the vapid refrain on p.156, it serves no other purpose in the novel. This is a clear example of what Genette (1993:25) would call parody, i.e. 'the distortion of a text by a minimal

32 In the Loeb translation of Campbell 1988:203-204, the poem is numbered 33. 
transformation [...]' with a view to mocking the text in question, or travesty, i.e. 'the stylistic transformation whose function is to debase [...]'.33

\subsubsection{Korydon and Kallirrhoe: Hellenistic romance}

While Aristotle and Stephanos are taking refuge in a mountain hut on their way to Delphi, they are joined by a young man called Korydon. He tells how he fell in love with and was betrothed to Kallirrhoe, the daughter of Habrokomes of Ephesos (161-164). Their happiness, however, was interrupted by Alexander's conquests as they were first separated and then threatened by the vicissitudes of war: enslavement, kidnapping, a siege, fire, capture by pirates, near-drowning, and attempted seduction by other suitors (165-177), the scene shifting from Miletos to Halikarnassos to Mytilene to Peiraieus. Thanks to a friend called Theron, Kallirrhoe was saved. After the three of them had been sold into slavery again (181), Korydon has now escaped from his master in Boiotia.

The romantic plot of Korydon's tale is loosely based on Chaereas and Kallirrhoe by Chariton, probably the earliest extant work of Greek prose fiction and thus the first European novel, perhaps to be dated to the middle of the first century AD (Reardon 1989:17). Doody retains the name of the female protagonist. Korydon is a name that also occurs in Theokritos; Habrokomes is a name she borrows from another ancient novel, An Ephesian tale by Xenophon of Ephesos (Reardon 1989:128ff.). An unusual change effected by Doody is the function of Theron: in Chariton he is a grave-robber, slave-seller, pirate, scoundrel; in Doody he becomes a trusted gay friend of Korydon and Kallirrhoe. Although the vicissitudes of Chaereas and Kallirrhoe contain even more twists and turns than those of Korydon and Kallirrhoe, both couples are portrayed as being involved in the siege of Tyre, the historical counterpart of which did in fact take place in 332 BC (Fox 1973:184-191).

The story told by Korydon of his and Kallirrhoe's adventures in Ionia takes up an inordinately large amount of space (156-187) in the novel. Although Korydon's entrance is justified, in that, like Aristotle and Stephanos, he is also searching for Kallirrhoe, the lovers' background adventures could have been drastically truncated. As it is, it consists of a concatenation of meandering scenes which the historical Aristotle would have described as episodic, merely

33 The use of terms such as 'mocking' and 'debase' indicates that parody or travesty undermines the register of the hypotext, thus frequently debunking an original which has an heroic register. It will be demonstrated that both these terms - parody and travesty - are sometimes relevant to Doody's transformation of her hypotexts, with the proviso that they can be applied to prose as well as to poetry, and that longer passages (in addition to individual words) can also be parodied. 
interrupting the fictional Aristotle's detective work without contributing anything material to it. Why, then, has Doody seen fit to include this digression?

One has to conclude that the hypotext of an ancient Greek novel posed too enticing a lure for Doody. With her expertise in the history of the novel, ${ }^{34}$ she probably could not resist the temptation of smuggling a hypertextual adaptation of various novelistic elements into her own novel.

\subsubsection{Kleobis and Biton: Herodotos debunked}

In Delphi, Aristotle and Stephanos encounter a stout matron who is trying to encourage her lacklustre sons, addressed as Kleobis and Biton, to help her pull a cart (195). Stephanos reminds the reader of 'the exemplary story of Kleobis and Biton, who harnessed themselves to the chariot of their mother, priestess of Hera, when she could not find horses, and drew her from Argos to the Temple of Hera, a distance of forty-five stadia. [...] In the morning the young men were found dead, having died peacefully in their sleep' (196). The cart-owner, however, dissuades the woman from following the example of the story, her sons proving less than competent (197). When, later, Korydon, in his search for Kallirrhoe, confronts one of them in a brothel, his conduct is also uninspiring (242-243).

The hypotext for this well-known story is Herodotos 1.30-33, where Kroisos reputedly asks Solon who was the happiest person ever. Kleobis and Biton, according to Solon, could be awarded the second prize after the Athenian Tellos.

It appears as if Doody's aim with the insertion of the unheroic Kleobis and Biton was the creation of a comic interlude, or perhaps the debunking (wimpification?) of the serious Herodotean hypotext. Once again, this fits Genette's definition of hypotextual adaptation for the purpose of parody or travesty.

\subsubsection{Euripides' Ion}

Still in Delphi, Stephanos nearly bumps into a little man who is eager to consult the Oracle. He turns out to be an anxious tomb-maker who is not averse to sharing his troubles with the public: 'Thirty-five — not a day younger. No children yet! Not even a bastard I can call my own, let alone one by poor Kreusa' (222). The mention of a childless Kreusa invites comparison with the unacknowledged hypotext of Euripides' Ion, where the couple Kreousa and Xouthos go on a serious mission to Delphi to consult the Oracle of Apollo about their childlessness. However, the tomb-maker's solipsist complaints are not developed any further and

34 http://www.nd.edu/ mdoody/. Retrieved 2010/08/04. 
do not contribute anything to the plot of the novel. One has to deduce, therefore, that this scene is inserted for comic relief, or for a hypertextual game that Genette would have called parody. Perhaps it provides an instance of what Marianne McDonald (1992:13), acknowledging Fredric Jameson, calls 'postmodern pastiche replacing parody'.

\section{Evaluation}

In the previous section, examples of Doody's use of hypertext were examined. In this section, they will be evaluated, with the modified version of Genette's scheme in Section 5 as hermeneutic paradigm.

(i) Examples of intertextuality occur when short passages are directly quoted from the Symposium (65-66), the Iliad (106), the Odyssey (210), the Orestes (309) and The Persians (360).

(ii) There are at least four examples of paratexts: the catchy title, which hints at the Poetics as a possible hypotext; the depiction, on the front cover, of Herakles attempting to steal Apollo's tripod, hinting at a Delphic setting; the plot summary on the back cover; and the List of Characters on pp.vi-viii. While this might be partly the responsibility of the design department of the publishing house, the reader will still perceive it as part of Doody's novel.

(iii) Architextuality is touched upon in that Aristotle discourses on the generic requirements for tragedy, epic poetry and comedy. ${ }^{35}$

(iv) Aristotle and poetic justice teems with examples of hypertextuality. There is no example of intrageneric hypertextuality, because there is no single ancient novel serving as hypotext for the whole of Doody's novel ${ }^{36}$ By Genette's criteria, the term transgeneric hypertextuality can be applied to all of the examples I have examined, because all of them have been adapted from other genres for use in a novel. This, then, would be descriptive of explicit references and implicit allusions to Homer, Hesiod, Aeschylos, Sophokles, Euripides, Herodotos, Aristophanes, Plato, Aristotle, Theophrastos and

35 See Pauw 2010:48-52.

36 One could argue that the Hellenistic novel Chaereas and Kallirrhoe serves as a relatively solid intrageneric hypotext, but I would reject the argument on account of the quantitative limitations of Chaereas and Kallirrhoe: it plays but a cameo role and is interjected in so episodic a way that it has very little influence on the plot of Doody's novel. 
Menander in the course of the novel. The Kleobis and Biton episode, for instance, has been adapted from historiography, Ion from tragedy, Anaxagoras and Lykidas from pastoral poetry, and Smikrines and Philomela from New Comedy. ${ }^{37}$ Moreover, of the examples I have examined, three provide clear evidence of the use of parody, travesty or persiflage. ${ }^{38}$

The term kaleidoscopic hypertext, I would suggest, is applicable when scattered allusions with a Greek flavour, more often than not mythological, are used to reinforce the classical atmosphere. Examples of this are provided where Philomela is described as running 'as fleet as Atlanta' (87); or when Stephanos sees the figure of Korydon following them: 'I saw it for only an instant, like a Pan-vision [...]' (149); or when Myrrhine addresses Aristotle as a 'peripatetic chresmologue' (289); or when Timotheos is described as 'jealous of Apollo himself - another Marsyas. Or like Thamyris who challenged the Muses and was blinded by them' (386). Although similes such as these would have been natural in most genres in postRenaissance literature, whatever the theme, in a twenty-first century detective novel they are perforce indicative of a Greek setting.

The genre of Doody's work clearly warrants the use of faction hypertextuality. Although her genre necessitates that not only the plot but also all the characters, including the seemingly historical, are fictional, her novel is solidly grounded in $330 \mathrm{BC}$ and biographical references to Alexander, Aristotle and Theophrastos, for instance, are in accord with the known historical facts gleaned from the works of the latter two authors and from historiographers. In fact, in a novel not without its defects, attention to historical detail is Doody's forte.

In evaluating the reception of Doody's novel, three considerations should be borne in mind. First, a distinction should be made between classicist and nonclassicist readers. One could assume that many of her classical allusions would be lost on the latter. This dichotomy in readers' reception is formulated as follows by Andrew Laird (1999:38): 'Instances of irony, parody, or stylization in texts or utterances — which are manifestations of intertextuality - are notorious for not being evident to everyone. Such qualities [...] are actualised only by readers or hearers with a certain competence'.

37 There are two hypotexts in Doody's novel which represent special cases of the category of transgeneric hypotexts in that they represent other genres and appear with frequency throughout the novel. They are the numerous allusions to Orestes and Elektra, representing tragedy, and the Poetics, representing literary criticism.

38 The Monkees, Kleobis and Biton, and Ion. 
In the second place, the question could be asked whether the allusion in question is intentional, or simply part of an inherited field of reference that is transmitted unconsciously.

Laird (1999:40) provides the following formulation of the problem: 'But where intertextuality is concerned, no explicit indication is given in a text or utterance of the presence of an alien text or speaker. Intertextuality [...] can often only be discerned when a text deviates from its customary tenor, whether in parody, stylization, irony, or in some other kind of variation which may or may not be recognized in conventional terms as an echo or allusion'.

How does the above relate to Doody? Suffice it to say that one can deduce from the context that all the examples listed in 6.2 and 6.3 represent instances of intentional intertextuality: it would surely be much more far-fetched for Doody's Menander or Xouthos or Korydon to interrupt the flow of a detective novel by accident than by design on her part. Readers armed with the knowledge of Doody's affinity for the literature of ancient Greece would expect her intertextuality to be intentional.

A third question relates to the direction of intentionality: can the linear movement of a diachronic influence be turned backwards ('anti-clockwise'), so that, for instance, Vergil's hypertext can be shown to 'influence' Homer's hypotext, or Vergilian 'traces' can be detected in Homer? Charles Martindale (1991:46) argues that '[s]ince Virgil, no reading of Homer [...] has been, or could $b e$, wholly free of a vestigial Virgilian presence - not even one given by an interpreter not directly familiar with Virgil's poems [...]'. Don Fowler (2000:130) thinks that such an approach does not pose a problem as long as intertextuality is located 'not in any pre-existing textual system but in the reader'. Thus, reading Euripides' Bacchants after Donna Tartt's The secret history, for instance, the reader will find it difficult not to associate the Theban sparagmos scene with a manslaughter committed by misguided college students on a cold New Hampshire night.

It has thus been shown that (i) (most) classicist readers will pick up intertextual allusions which non-classicists will most probably miss; (ii) Doody's use of intertext, whether explicit or implicit, can be taken to be intentional; and (iii) it is a valid reading strategy to detect 'anti-clockwise' intertextual influences (i.e. where hypertext influences hypotext).

The last point relates to Genette's term palimpsest, mentioned in Section 5. The application of this term to Doody's novel implies that a classicist will not be able to re-read certain classical passages without recalling her hypertextual adaptation of the passages in question. Linda Hutcheon (2006:121) describes this process, as applied to theatre and film studies, as follows: 'If we know the [adapted] work(s) in question, we become a knowing audience, and part of what 
hermeneutic theory calls our 'horizon of expectation' involves that adapted text. What is intriguing is that, afterward, we often come to see the prior adapted work very differently as we compare it to the result of the adapter's creative and interpretative act'. Doody's novel thus becomes a palimpsest through which the original passages can be (re-)read as not merely cast in bronze, but as subject to adaptation or transformation. After exposure to Doody's debunking exercise, the heroic status of Herodotus' mythologised Kleobis and Biton, for instance, will be implicitly questioned; readers will be more susceptible to the possibility that Euripides' Xouthos has a comical side (if not that he is in fact a tomb-maker!); a re-reading of the prooimion of Hesiod's Theogony will always remind one of its adaptation on the first page of Aristotle and poetic justice. Thus, any further 'innocent' reading of Doody's hypotexts by a classicist has been irrevocably undermined by exposure to this palimpsest.

\section{Conclusion}

In an article which warns against the ideological pitfalls of conventional classical canons, Seth L Schein (2008:84) argues that '[w]e classical scholars and teachers have a particular opportunity and responsibility to understand and resist the institutional construction of a self-serving literary canon and classical tradition [...]. Our work becomes easier when we free ourselves from the assumption of elitism that has traditionally been associated with the classical'. Schein's cautioning note echoes the sentiments of Peter Green (1989:25), who describes the response of many classicists to the challenges of modernism as elitist: 'When modernists dismissed this attitude as anti-egalitarian (which it was) [...], traditional humanists $[\ldots]$ clung to the classics as the embodiment of good taste, the proper intellectual training for a corps of post-Platonic Guardians whose business was government and whose leisure, what the Romans termed otium, embraced such interesting minor skills as pastiching English poetry into Greek or Latin verse'. This perception clearly had to change if the classics were to survive.

One strategy for survival over the last two generations has, predictably and for the most part laudably, been popularisation. At the University of Stellenbosch, for instance, courses in Classical Culture initiated in 1962 by Prof. Pieter Conradie, Prof. Frans Smuts and Dr. André Hugo (Conradie 1994:42) would later prove to offset the dwindling number of students in Greek (as market forces hit theology students) and Latin (when the latter was abolished as prerequisite for law degrees). Many of these courses involved comparative literature and thus what would later be called intertext, adaptation or reception studies.

Linda Hutcheon (2006:176) ascribes the following function to adaptations in general: 'An adaptation is not vampiric: it does not draw the life-blood from its 
source and leave it dying or dead, nor is it paler than the adapted work. It may, on the contrary, keep that prior work alive, giving it an afterlife it would never have had otherwise'. If one applies Hutcheon's judgement to literary adaptation, I think that non-classicist readers would rather opt for discovering the world of Cicero via the (mis)adventures of Gordianus the Finder than struggling through Cicero's courtroom speeches. Again, those unacquainted with Ovid's Tristia might be lured to the world of Ovid by Christoph Ransmayr's quaint postmodern novel Die letzte Welt. Reading Mary Renault's The bull from the sea might be a stronger incentive to visit Knossos than perusing Arthur Evans' excavation reports would be. By the same logic, many non-classicists reading Doody's novel for the sake of a whodunnit will unwittingly become acquainted with the world of Aristotle and thus, perhaps, become converts to the classics. Such a Trojan Horse technique is, I think, perfectly justifiable in an age when cultural literacy is dwindling and the same readers are very unlikely to read a translation of the Poetics or an academic book about Aristotle; in fact, it would already constitute a victory for the Classics to let them read Doody instead of limiting their intellectual stimuli to playing computer games or teletexting.

In evaluating the reception of classical works, Lorna Hardwick (2003:112) asks three questions, of which the first two are relevant here: 'Firstly, have the artists 'made' or created a work which differs in significant respects from the classical text or image? [...] Secondly, how does the imitation, analogue or new work affect perceptions of the ancient world? Does it prompt the receiving individuals or groups to revisit the ancient works, perhaps to find elements which had been concealed or marginalized [...]?'

While the latter question would necessitate empirical reception studies which are beyond my ken, one could speculate that even non-classicist readers of Doody's novel would at least be prompted to find out more about Aristotle, to read up on Orestes and Elektra, or to use Doody's ekphrasis of Delphi as a Baedecker or a Pausanias when visiting Delphi in person. If this were to be the case, her use of literary and historical intertexts could be deemed to be successful as a popularising strategy.

In Aristotelian terms, 'history' deals with ephemeral particulars and 'poetry' with timeless universals. ${ }^{39}$ According to this paradigm, the literary recipe for a murder mystery provides the 'poetic' matrix — the skeleton, as it were - which is then fleshed out with the details of the specific case. By imbuing her skeleton with the life of Greece in $330 \mathrm{BC}$ and the letters of archaic and classical Greece, Margaret Doody has provided her readers with a hypertext that keeps the classical hypotext alive.

39 Aristotle, Poetics $1451 \mathrm{~b}$. 


\section{BIBLIOGRAPHY}

Badian E 1999. Der Neue Pauly. Enzyklopädie der Antike 7.1204-5. Memnon [3] \& Memnon [4]. Hrsg. von H Cancik \& H Schneider. Stuttgart: Metzler.

Campbell D A (trans.) 1988. Greek Lyric. Vol. 2. Anacreon, Anacreontea, choral lyric from Olympus to Alcman (Loeb). Cambridge, Mass.: Harvard University Press.

Conradie P J 1994. Klassieke Kultuur op Stellenbosch. Akroterion 39.1:42-44.

De Marre M 1988. Revenge and / or justice. The portrayal of Electra in drama with special reference to the modern plays of Hofmannsthal, O'Neill, Giraudoux and Yourcenar. M A Thesis. Stellenbosch University.

Doody M 2002. Aristotle and poetic justice. London: Random House.

Eco U 1979. The role of the reader. Bloomington: Indiana University Press.

Fowler D 2000. Roman constructions. Readings in postmodern Latin. Oxford: Oxford University Press.

Fox R L 1973. Alexander the Great. London: Futura Publications.

Genette G 1993. Palimpsests: Literature in the second degree (trans. by $\mathrm{C}$ Newman \& C Doubinsky). Lincoln \& London: University of Nebraska Press.

Green P 1989. Classical bearings. Interpreting ancient history and culture. London: Thames \& Hudson.

Hardwick L 2003. Reception Studies. Greece \& Rome New Surveys in the Classics No. 33. Oxford: Oxford University Press.

Holden A (trans. \& introd.) 1974. Greek pastoral poetry. Harmondsworth: Penguin Books.

Hutcheon L 2006. A theory of adaptation. London: Routledge.

Laird A 1999. Powers of expression, expressions of power. Speech presentation and Latin literature. Oxford: Oxford University Press.

Martindale C 1991. Redeeming the text: The validity of comparisons of Classical and Post-classical literature (a view from Britain). Arion $3^{\text {rd }}$ Series 1.3:45-75.

McDonald M 1992. Ancient sun, modern light. Greek drama on the modern stage. New York: Columbia University Press.

Mench F W 1993. Historical novels of Ancient Rome in the classroom. Classical World 87.1: 49-54.

Miller N (trans. \& introd.) 1987. Menander. Plays and fragments. Harmondsworth: Penguin Books.

Pauw F R 1994. 'If on a winter's night a reveller': The classical intertext in Donna Tartt's The secret history, Part 1. Akroterion 39.3-4:141-163.

Pauw F R 1995. 'If on a winter's night a reveller': The classical intertext in Donna Tartt's The secret history, Part 2. Akroterion 40.1:1-26. 
Pauw F R 2009. William Golding's The double tongue as hypertext of Euripides's Ion. Acta Classica 51:125-144.

Pauw F R 2010. Aristotle's Poetics in Margaret Doody's Aristotle and poetic justice. Acta Academica 26-60.

Reardon B P (ed.) 1989. Collected ancient Greek novels. Berkeley: University of California Press.

Scarborough J 2009. Review of Millet P 2007. Theophrastos and his world. Proceedings of the Cambridge Philological Society, Supplement Vol. 33. Cambridge: Cambridge University Press. Bryn Mawr Classical Review 2009.10.55. (bmcreview=brynmawr.edu@ mscv6.net)

Schein S L 2008. 'Our debt to Greece and Rome': Canon, class and ideology. In Hardwick L \& Stray C (ed.), A companion to classical receptions, 75-85. London: Blackwell.

Segal E 1969. The Menaechmi: Roman comedy of errors. Yale Classical Studies 21:77-93.

Sommerstein A H (trans. \& introd.) 1973. Aristophanes. Lysistrata / The Acharnians / The clouds. Harmondsworth: Penguin Books.

Sullivan J P 1994. Introduction. Critical continuity and contemporary innovation. In De Jong I J F \& Sullivan J P (ed.). Modern critical theory and classical literature, 1-26. Leiden: Brill.

Von Geisau H 1979. Der Kleine Pauly. Lexicon der Antike 3.1183 Melpomene. München: Deutscher Taschenbuch Verlag.

Von Geisau H 1979. Der Kleine Pauly. Lexicon der Antike 5.643 Thaleia. München: Deutscher Taschenbuch Verlag.

Wiesehöfer J 2000. Der Neue Pauly. Enzyklopädie der Antike 9.50-51. Orontopates. Hrsg. von H Cancik \& H Schneider. Stuttgart: Metzler. 